\title{
The Korean Severe Asthma Registry (KoSAR): real world research in severe asthma
}

\author{
Sang-Heon Kim', Hyun Lee', So-Young Park ${ }^{2}$, So Young Park³ , Woo-Jung Song ${ }^{4}$, Joo-Hee Kim5, Heung-Woo Park ${ }^{6}$, \\ You Sook $\mathrm{Cho}^{4}$, Ho Joo Yoon ${ }^{1}$, and on behalf of the KoSAR investigators
}

\begin{abstract}
'Department of Internal Medicine, Hanyang University College of Medicine, Seoul; ${ }^{2}$ Division of Pulmonary, Allergy, and Critical Care Medicine, Department of Internal Medicine, Chung-Ang University College of Medicine, Seoul; ${ }^{3}$ Department of Internal Medicine, Eulji General Hospital, Eulji University School of Medicine, Seoul; ${ }^{4}$ Department of Allergy and Clinical Immunology, Asan Medical Center, University of Ulsan College of Medicine, Seoul; ${ }^{5}$ Department of Internal Medicine, Hallym University Sacred Heart Hospital, Anyang; ${ }^{6}$ Department of Internal Medicine, Seoul National University College of Medicine, Seoul, Korea
\end{abstract}

Received : August 30, 2021 Accepted: December 17, 2021

\begin{abstract}
Severe asthma constitutes a serious health burden with significant morbidity and socioeconomic costs. The development and introduction of new biologics targeting type 2 inflammation changed the paradigm for management of severe asthma and initiated a biological era. These changes impose a challenge to clinicians in managing difficult-to-treat and severe asthma. To understand the characteristics and heterogeneity of severe asthma and to develop a better strategy to manage it, the Korean Academy of Asthma, Allergy and Clinical Immunology, Working Group on Severe Asthma, has organized the Korean Severe Asthma Registry (KoSAR). In this review, we describe the challenges of severe asthma management regarding diagnosis, disease burden, heterogeneity, guidelines, and organization of severe asthma clinics. This review also examines the current global activities of national and regional registries and study groups. In addition, we present the KOSAR vision and organization and describe the findings of KOSAR in comparison with those of other countries.
\end{abstract}

Keywords: Severe asthma; Registries; Biological products; Real world

Correspondence to You Sook Cho, M.D.

Division of Allergy and Clinical Immunology, Department of Internal Medicine, Asan Medical Center, University of Ulsan College of Medicine, 88 Olympic-ro 43-gil, Songpa-gu, Seoul 05505, Korea

Tel: +82-2-3010-3285, Fax: +82-2-3010-6969, E-mail: yscho@amc.seoul.kr https://orcid.org/0000-0001-8767-2667

\section{INTRODUCTION}

With implementation of preventive and therapeutic strategies for asthma at national and clinical levels, there has been a notable improvement in the outcomes. However, recent analyses using Korean National Health Insurance Service (NHIS) data showed that the overall prevalence of and mortality from asthma remain high [1]. Asthma-related death and frequent hospitalization due to acute exacerbations mostly occur in patients with uncontrolled and severe asthma. Moreover, severe asthma is linked to high use of healthcare facilities and high economic costs [2].
The substantial burden of severe asthma has been a driving force in the development of novel drugs. Following the introduction of anti-immunoglobulin E ( $\operatorname{lgE})$ antibody, the first biologic for severe asthma, monoclonal antibodies targeting interleukin 5 (IL-5), IL-5 receptor (IL-5R), or IL-4R have been developed and approved for treatment of severe asthma. Furthermore, several more novel drugs targeting other critical molecules in the pathogenesis of severe asthma are under development. The availability of new biological agents has created a novel paradigm for management of severe asthma [3], addressing a number of issues.

To understand severe asthma and to address various is- 
sues regarding its management, national and international registries have been developed. In Korea, a national registry of severe asthma has been established by the Korean Academy of Asthma, Allergy and Clinical Immunology (KAAACI), Working Group on Severe Asthma, and named the Korean Severe Asthma Registry (KoSAR) [4]. The present paper describes the challenges in the management of severe asthma and the relevant global research. This paper also presents the vision, organization, and findings of the KOSAR.

\section{CHALLENGES OF SEVERE ASTHMA MAN- AGEMENT}

\section{Defining severe asthma}

In the treatment of asthma, stepwise approaches are recommended to achieve and maintain asthma control (Fig. 1). Severe asthma often is defined as uncontrolled asthma despite the use of higher treatment steps and correction of modifiable factors. While various definitions of severe asthma have been suggested by international and national organizations, the major criteria for diagnosis include uncontrolled asthma symptoms, frequent exacerbations, lung function decline, and requirement of a higher treatment level (Table 1) [5-7]. Complexity in the determination of the levels of asthma control and asthma severity leads to challenges for clinicians. Difficulties in identifying severe asthma might contribute to a low referral rate and a high proportion of unrecognized severe asthma cases in primary care [8].

In an expert opinion paper by the KAAACI [9], we suggested an integrated approach to uncontrolled asthma, difficult-to-treat asthma, and severe asthma. Criteria for uncontrolled asthma included frequent symptoms day and

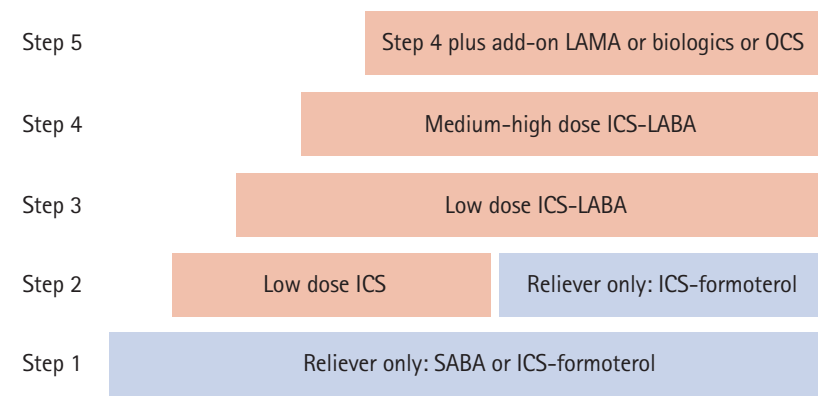

Figure 1. Stepwise approach for asthma management. LAMA, long-acting muscarinic antagonist; OCS, oral corticosteroid; ICS, inhaled corticosteroid; LABA, long-acting beta2 agonist. night, frequent use of a reliever, any activity limitation, reduced lung function, and history of exacerbation in the previous year. Confirmation of asthma diagnosis, correction of modifiable risk factors, and control of comorbidities are required in the evaluation of difficult-to-treat asthma. We recommended referral of patients with severe asthma to asthma specialists or severe asthma clinics for phenotype assessment and use of add-on medications like biologics.

\section{Epidemiology and disease burden in Korea}

The prevalence of severe asthma is estimated to be about $5 \%$ to $10 \%$ of all asthma patients [10], but this prevalence varies depending on the definition of severe asthma and the study population. Data from the Korean NHIS showed that the prevalence of severe asthma has increased over the past decade [1]. Asthma specialists in Korea estimated that $13.9 \%$ of the asthma patients presenting to their clinics have severe asthma [11]. Despite the low proportion of severe asthma patients, mortality and economic costs are much higher in patients with severe asthma than in those with mild to moderate disease [12]. Moreover, systemic corticosteroids are used frequently for exacerbations and maintenance of severe asthma. Analysis of the asthma medications used in treatment in Korea showed a strikingly high number of patients using oral corticosteroids (OCS), while the use of inhaled corticosteroids (ICS) is low [13]. These findings suggest that the asthma guidelines have not been adopted and applied uniformly by the primary care physicians in Korea [14]. Analysis of data from 11 national registries of severe asthma in Europe showed that OCS maintenance is common, ranging in prevalence from $21.0 \%$ to $63.0 \%$ [15]. Higher chronic use of OCS leads to increased risk of complications, costs, and dose-dependent mortality [16-18]. Furthermore, patients with severe asthma experience severe physical and psychological distress from exacerbations [19]. Nonetheless, physicians and regulatory authorities have not acknowledged the extent of the severe asthma burden.

\section{Heterogeneity of severe asthma}

As with asthma, severe asthma is heterogeneous with multiple phenotypes and endotypes [20]. Phenotypes of asthma can be determined and classified into various categories by clinical, trigger-related, or inflammatory characteristics [21]. While allergic/non-allergic phenotypes and intrinsic/extrinsic phenotypes were used for a long time, inflammatory phenotypes, which can be determined as eosinophilic, neutro- 
Table 1. Definitions of uncontrolled, difficult-to-treat, and severe asthma

\begin{tabular}{|c|c|c|c|}
\hline & GINA & ERS/ATS & KAAACI \\
\hline $\begin{array}{l}\text { Uncontrolled } \\
\text { asthma }\end{array}$ & $\begin{array}{l}\text { Uncontrolled asthma includes } \\
\text { one or both of the followings: } \\
\text { Poor symptom control } \\
\text { (frequent symptoms or re- } \\
\text { liever use, activity limited by } \\
\text { asthma, night waking due } \\
\text { to asthma) } \\
\text { Frequent exacerbations } \\
\text { ( } \geq 2 / \text { year) requiring OCS, } \\
\text { or serious exacerbations } \\
\text { ( } \geq 1 / \text { year) requiring } \\
\text { hospitalization }\end{array}$ & $\begin{array}{l}\text { Uncontrolled asthma defined as at least one } \\
\text { of the following: } \\
\text { Poor symptom control: ACQ consistently } \\
>1.5, A C T>20 \text { (or "not well controlled" } \\
\text { by NAEPP/GINA guidelines) } \\
\text { Frequent severe exacerbations: two or } \\
\text { more bursts of systemic CS ( }>3 \text { days } \\
\text { each) in the previous year } \\
\text { Serious exacerbations: at least one } \\
\text { hospitalization, ICU stay or mechanical } \\
\text { ventilation in the previous year } \\
\text { Airflow limitation: after appropriate } \\
\text { bronchodilator withhold FEV }{ }_{1}^{<} 80 \% \\
\text { predicted (in the face of reduced FEV }{ }_{1} / \\
\text { FVC defined as less than the lower limit } \\
\text { of normal) }\end{array}$ & $\begin{array}{l}\text { Uncontrolled asthma symptom } \\
\text { ( } 3 \text { or } 4 \text { of criteria) } \\
\geq 2 \text { Daytime symptoms/weeks in } \\
\text { the past } 4 \text { weeks } \\
\text { Any night waking in the past } 4 \text { weeks } \\
\text { Reliever used } \geq 2 / \text { week in the past } 4 \\
\text { weeks } \\
\text { Any activity limitation in the past } 4 \\
\text { weeks } \\
\text { OR } \\
\text { Partly controlled asthma symptom (1 } \\
\text { or } 2 \text { criteria) plus one risk factor for } \\
\text { poor outcome } \\
\text { Reduced lung function (FEV } 1 \text { predict- } \\
\text { ed value } \leq 80 \% \text { ) } \\
\text { History of asthma exacerbation (OCS } \\
\text { bursts } \geq 2 / \text { year or hospitalization } \geq \\
1 / \text { year) }\end{array}$ \\
\hline $\begin{array}{l}\text { Difficult-to-treat } \\
\text { asthma }\end{array}$ & $\begin{array}{l}\text { Asthma that is uncontrolled de- } \\
\text { spite prescribing of medium or } \\
\text { high dose ICS-LABA treatment } \\
\text { or that requires high dose } \\
\text { ICS-LABA treatment to main- } \\
\text { tain good symptom control } \\
\text { and reduce exacerbations. }\end{array}$ & $\begin{array}{l}\text { Difficult asthma include uncontrolled asth- } \\
\text { ma in whom appropriate diagnosis and/ } \\
\text { or assessment of confounding factors and } \\
\text { comorbidities vastly improves their current } \\
\text { condition. }\end{array}$ & $\begin{array}{l}\text { Asthma that is uncontrolled with } \\
\text { GINA step } 4 \text { or } 5 \text { treatment }\end{array}$ \\
\hline Severe asthma & $\begin{array}{l}\text { Asthma that is uncontrolled de- } \\
\text { spite adherence with optimized } \\
\text { high dose ICS-LABA therapy } \\
\text { and treatment of contributory } \\
\text { factors, or that worsens when } \\
\text { high dose treatment is de- } \\
\text { creased. }\end{array}$ & $\begin{array}{l}\text { Asthma which requires treatment with } \\
\text { guidelines suggested medications for GINA } \\
\text { steps 4-5 asthma (high dose ICS and LABA } \\
\text { or leukotriene modifier/theophylline) for } \\
\text { the previous year or systemic CS for } \geq 50 \% \\
\text { of the previous year to prevent it from be- } \\
\text { coming "uncontrolled" or which remains } \\
\text { "uncontrolled" despite this therapy } \\
\text { Controlled asthma that worsens on taper- } \\
\text { ing of these high doses of ICS or systemic } \\
\text { CS (or additional biologics) }\end{array}$ & $\begin{array}{l}\text { Asthma that is still uncontrolled after } \\
3-6 \text { months of optimizing treatment } \\
\text { including both pharmacological and } \\
\text { non-pharmacological treatment: } \\
\text { Confirmation of asthma diagnosis } \\
\text { Correction of modifiable risk factors } \\
\text { Control of comorbidities }\end{array}$ \\
\hline
\end{tabular}

GINA, Global Initiative for Asthma; ERS, European Respiratory Society; ATS, American Thoracic Society; KAAACI, Korean Academy of Asthma, Allergy and Clinical Immunology; OCS, oral corticosteroid; ACQ, Asthma Control Questionnaire; ACT, Asthma Control Test; NAEPP, National Asthma Education and Prevention Program; CS, corticosteroid; ICU, intensive care unit; FEV ${ }_{1}$, forced expiratory volume in 1 second; FVC, forced vital capacity; ICS, inhaled corticosteroid; LABA, long-acting beta2 agonist.

philic, or pauci-granulocytic, are also useful to guide the pharmacological treatment of severe asthma. In addition, endotypes of severe asthma can be defined by different mechanisms underlying severe asthma and networks of the innate and adaptive immune responses [22]. Ongoing researches on the phenotypes and endotypes of severe asth- ma would enhance our understanding of the pathobiology of severe asthma and develop precision medicine in severe asthma.

Responses to medications can differ according to demographic and clinical characteristics. Particularly, biologics targeting type 2 cytokines and IgE showed significant efficacy 
in asthma outcomes such as exacerbations and lung function. These biologics are approved for use in patients with severe asthma with type 2 inflammation, characterized by eosinophilic and allergic phenotypes [23]. Moreover, there is a variety of treatable traits that require identification in patients with severe asthma $[24,25]$. While comorbid chronic obstructive pulmonary disease (COPD) in severe asthma usually is diagnosed as asthma-COPD overlap (ACO), determination of COPD might not be consistent among specialists [26]. The prevalence of ACO is especially high in older male patients with severe asthma [27]. There is little evidence regarding pharmacological treatment of ACO [28].

Various biomarkers are utilized to determine phenotypes, endotypes, and treatable traits of severe asthma. Notably, type 2 biomarkers, such as blood and sputum eosinophils, exhaled nitric oxide, and skin test positivity to perennial allergens, play important roles in determining which patients would benefit from biological agent therapy [29]. However, a questionnaire survey among asthma specialists in Korea suggested that phenotyping of severe asthma and application of various diagnostic tests are not widespread [11].

\section{Guidelines for severe asthma}

With the introduction of biologics in the management of severe asthma, there has been a growing demand for practical guidelines. To meet this demand and assist practitioners in treating severe asthma, the Global Initiative for Asthma (GINA) published a 2019 pocket guide, 'Diagnosis and Management of Difficult-to-treat and Severe Asthma in Adolescent and Adult Patients.' This guide later was incorporated into a main report [30]. In addition, new European Respiratory Society (ERS)/American Thoracic Society (ATS) guidelines were published focusing on the pharmacological treatment of severe asthma including biologics (anti-IL5, anti-IL5R, and anti-IL4Ra), long-acting muscarinic antagonists (LAMA), and macrolides [29]. The European Academy of Allergy and Clinical Immunology (EAACI) also published guideline on the use of biologics for severe asthma [23]. Some countries including Canada [31], China [32], and those in Latin America [33], published their national guidelines or position papers on difficult-to-treat asthma and severe asthma. The Working Group on Severe Asthma of the $\mathrm{KAAACl}$, issued an expert opinion paper on evaluation and management of difficult-to-treat asthma and severe asthma [9]. International and national guidelines or position papers on severe asthma are described in Table 2. These guidelines require updating to include new therapeutic agents for severe asthma such as triple therapy in a single inhaler [34-

Table 2. National and international guidelines and position papers regarding severe asthma

\begin{tabular}{|c|c|c|c|}
\hline Title of guidelines or position paper (year) & Country & Organization & Reference \\
\hline $\begin{array}{l}\text { GINA pocket guide, Diagnosis and management of diffi- } \\
\text { cult-to-treat and severe asthma in adolescent and adult } \\
\text { patients (2019) }\end{array}$ & International & GINA & [30] \\
\hline $\begin{array}{l}\text { Management of severe asthma: a European Respiratory Soci- } \\
\text { ety/American Thoracic Society guideline (2020) }\end{array}$ & $\begin{array}{l}\text { Europe and United } \\
\text { States }\end{array}$ & ERS and ATS & [29] \\
\hline $\begin{array}{l}\text { EAACI Biologicals Guidelines-recommendations for severe } \\
\text { asthma }\end{array}$ & Europe & EAACl & {$[23]$} \\
\hline $\begin{array}{l}\text { Recognition and management of severe asthma: a Canadian } \\
\text { Thoracic Society position statement (2017) }\end{array}$ & Canada & Canadian Thoracic Society & [31] \\
\hline $\begin{array}{l}\text { Chinese expert consensus on diagnosis and management of } \\
\text { severe asthma (2018) }\end{array}$ & China & $\begin{array}{l}\text { Asthma Workgroup of the Chinese } \\
\text { Thoracic Society, Chinese Medical } \\
\text { Association, and China Asthma } \\
\text { Alliance }\end{array}$ & {$[32]$} \\
\hline $\begin{array}{l}\text { Evaluation and management of difficult-to-treat and severe } \\
\text { asthma: an expert opinion (2020) }\end{array}$ & Korea & $\begin{array}{l}\text { KAAACl, Working Group on Severe } \\
\text { Asthma }\end{array}$ & {$[9]$} \\
\hline $\begin{array}{l}\text { Severe asthma: adding new evidence: Latin American Thoracic } \\
\text { Society (2021) }\end{array}$ & Latin America & Latin America Thoracic Society & [33] \\
\hline
\end{tabular}

GINA, Global Initiative for Asthma; ERS, European Respiratory Society; ATS, American Thoracic Society; EAACl, European Academy of Allergy and Clinical Immunology; KAAACI, Korean Academy of Asthma, Allergy and Clinical Immunology. 
Table 3. Capacity required for specialized severe asthma clinics

\begin{tabular}{|c|c|c|}
\hline Category & Purpose & Service or facility \\
\hline Diagnosis & $\begin{array}{l}\text { Confirmation of diagnosis of asthma } \\
\text { Differential diagnosis of asthma } \\
\text { Assessment of level of asthma control }\end{array}$ & $\begin{array}{l}\text { Spirometry } \\
\text { Bronchodilator response } \\
\text { Bronchial provocation test } \\
\text { Chest CT } \\
\text { Bronchoscopy } \\
\text { Laryngoscopy } \\
\text { Laboratory tests: anti-neutrophil cytoplasmic antibodies }\end{array}$ \\
\hline Phenotyping & $\begin{array}{l}\text { Evaluation of inflammatory and immunological } \\
\text { phenotypes }\end{array}$ & $\begin{array}{l}\text { Blood and sputum eosinophils (sputum induction and process- } \\
\text { ing) exhaled nitric oxide skin tests and serum-specific lgE }\end{array}$ \\
\hline Comorbidities & $\begin{array}{l}\text { Assessment of comorbidities } \\
\text { Treatment of comorbidities } \\
\text { Multidisciplinary care }\end{array}$ & $\begin{array}{l}\text { Management of chronic rhinosinusitis, GERD, sleep apnea, obe- } \\
\text { sity, aspirin hypersensitivity, depression, and anxiety disorder } \\
\text { multidisciplinary team } \\
\text { Specialty consultation: allergists, pulmonologists, otolaryngolo- } \\
\text { gists, psychiatrists }\end{array}$ \\
\hline Medications & $\begin{array}{l}\text { Controllers including biologics } \\
\text { Adverse reactions to asthma medications }\end{array}$ & $\begin{array}{l}\text { Facilities for biologics medications: injection and monitoring of } \\
\text { adverse reactions } \\
\text { Emergency care for anaphylaxis }\end{array}$ \\
\hline $\begin{array}{l}\text { Patient } \\
\text { education }\end{array}$ & $\begin{array}{l}\text { Understanding asthma and severe asthma } \\
\text { Action plan for exacerbation } \\
\text { Inhaler technique } \\
\text { Selection of appropriate inhalers } \\
\text { Smoking cessation } \\
\text { Environmental control }\end{array}$ & $\begin{array}{l}\text { Patient education program } \\
\text { Specialist nurses and pharmacists } \\
\text { Education materials and resources }\end{array}$ \\
\hline Referral & $\begin{array}{l}\text { Partnership with general physicians } \\
\text { Recognition of severe asthma in primary care }\end{array}$ & $\begin{array}{l}\text { Education of the general physicians } \\
\text { Referral system from primary clinics }\end{array}$ \\
\hline
\end{tabular}

CT, computed tomography; IgE, immunoglobulin E; GERD, gastroesophageal reflux disease.

36]. For those who did not show good response to type 2-targeted therapy and those without evidence of type 2 inflammation, azithromycin or low dose OCS should be considered as add-on treatment.

\section{Setting up severe asthma clinics}

While most patients with asthma are managed by primary care physicians, severe asthma management should be performed at a specialty center [37]. This level of treatment facility optimizes the possibility of favorable treatment results [38]. Approaches to uncontrolled asthma include confirmation of asthma, evaluation of comorbidities, and use of advanced medications based on asthma phenotype. Thus, asthma guidelines underscore the necessity of specialist referral of patients in whom asthma is uncontrolled despite the use of advanced treatments $[30,39]$. To provide comprehensive and specialized care, severe asthma clinics or centers should be equipped with appropriate facilities and specialists, including physicians, nurses, and pharmacists [40]. Moreover, a multidisciplinary or interdisciplinary approach to uncontrolled asthma leads to improved treatment outcomes [41]. Table 3 describes the roles and capacities of severe asthma clinics. Education of patients should be one of the major services of severe asthma clinics since correction of poor treatment adherence and inhaler technique can be improved to reduce the need for OCS and hospitalization [42]. Given that the proportion of current smokers in Korean subjects is higher than in other countries [4], a smoking cessation program should be a part of the severe asthma clinic services. Recognition and referral of patients with severe asthma from primary care could be derived by setting up partnership between primary care and severe asthma clinics and education program of the general physicians. 


\section{REGISTRIES AND STUDY GROUPS ON SEVERE ASTHMA}

\section{Strengths and opportunities of a severe asthma registry}

Registries of severe asthma can offer valuable opportunities to assess the demographic and clinical characteristics of patients in addition to the assessment of actual treatment responses and adverse reactions of heterogeneous severe asthma [43]. In addition to baseline characteristics, registry follow-up information would include the long-term course of severe asthma according to phenotype and treatment. National severe asthma registries deliver country-specific information and knowledge from enrolled subjects managed by country-specific healthcare and referral systems. Many countries, including the United Kingdom [44], Italy [45], France [46], Belgium [47], Spain [48], Portugal [49], Austria [50], Germany [51], and Russia [52], the United States [53], Korea [4], and Austalia [54], have established national registries (Table 4).

In addition to national registries, international or regional registries create the possibility for comparison of patient characteristics between countries. The ERS launched a clinical research collaboration on severe asthma in 2018, the Severe Heterogeneous Asthma Research collaboration, Patient-centred (SHARP) [55]. Comparisons of the characteristics and treatment of severe asthma by the SHARP showed wide variation and heterogeneity across 11 European countries [15]. A regional registry of the African Severe Asthma Project (ASAP) showed unique characteristics of severe asth-

Table 4. National and international registries and study groups focused on severe asthma

\begin{tabular}{|c|c|c|c|}
\hline Name & Country & Organization & Reference \\
\hline \multicolumn{4}{|l|}{ National: Europe } \\
\hline UK Severe Asthma Registry (UKSAR) & United Kingdom & BTS & [44] \\
\hline Severe Asthma Network in Italy (SANI) registry & Italy & SANI & [45] \\
\hline COhort of BRonchial obstruction and Asthma (COBRA) & France & & [46] \\
\hline Belgian Severe Asthma Registry (BSAR) & Belgium & Belgian Thoracic Society & [47] \\
\hline Spanish Registry of Severe Asthma & Spain & & [48] \\
\hline Portuguese Severe Asthma Registry & Portugal & REAG & [49] \\
\hline Austrian Severe Asthma Registry & Austria & $\begin{array}{l}\text { Austrian Severe Asthma Net } \\
\text { (ASA-Net) }\end{array}$ & [50] \\
\hline German Severe Asthma Registry & Germany & German Asthma Net & [51] \\
\hline Russian Severe Asthma Registry (RSAR) & Russia & Russian Respiratory Society & [52] \\
\hline \multicolumn{4}{|l|}{ National: North America } \\
\hline CHRONICLE & United States & & [53] \\
\hline Severe Asthma Research Program (SARP) & United States & & [58] \\
\hline \multicolumn{4}{|l|}{ National: Asia-Pacific } \\
\hline Korean Severe Asthma Registry (KoSAR) & Korea & $\mathrm{KAAACl}$ & {$[4]$} \\
\hline Australian Severe Asthma Registry (ASAR) & Australia & $\begin{array}{l}\text { Australian Severe Asthma } \\
\text { Network (ASAN), TSANZ }\end{array}$ & [54] \\
\hline \multicolumn{4}{|l|}{ International } \\
\hline $\begin{array}{l}\text { Severe Heterogeneous Asthma Research collaboration, } \\
\text { Patient-centred (SHARP) }\end{array}$ & Europe & ERS & [55] \\
\hline African Severe Asthma Project (ASAP) & Africa & & [56] \\
\hline International Severe Asthma Registry (ISAR) & World & & [57] \\
\hline $\begin{array}{l}\text { Unbiased Biomarkers for the Prediction of Respiratory } \\
\text { Disease Outcomes (U-BIOPRED) }\end{array}$ & Europe & & [60] \\
\hline
\end{tabular}

BTS, British Thoracic Society; REAG, Rede de Especialistas em Asma Grave; KAAACI, Korean Academy of Asthma, Allergy and Clinical Immunology; TSANZ, Thoracic Society of Australia and New Zealand; ERS, European Respiratory Society. 
ma in East Africa (Uganda, Kenya, and Ethiopia), where only $14.0 \%$ of patients, including severe asthma patients, used ICS [56]. The International Severe Asthma Registry (ISAR) was organized to collect data from national registries for comparison across countries [57]. Such sufficiently large datasets could generate reliable and powerful answers to various research questions.

\section{Study consortiums on the mechanisms of severe asthma}

Unlike the national and international registries, there are study groups to address the mechanisms of severe asthma. The U.S. Severe Asthma Research Program (SARP) is a US research consortium established by the National Heart, Lung, and Blood Institute of the National Institutes of Health in 2011 [58]. Investigators in the SARP recruited a large number of asthma patients and explored the heterogeneity of severe asthma using various clinical, genetic, imaging, and biomarker analyses [59]. In Europe, the Innovative Medicines Initiative (IMI)-funded consortium Unbiased BIOmarkers for the Prediction of REspiratory Disease outcomes (U-BIOPRED) improved our understanding of the mechanisms of severe asthma using a systems biology approach [60].

\section{KOREAN SEVERE ASTHMA REGISTRY}

\section{Vision and organization}

The KoSAR (https://severeasthmawg.com) was established in 2011, by the KAAACl, Working Group on Severe Asthma. This registry aimed to assess the demographics, clinical characteristics, and heterogeneous phenotypes of severe asthma. We also gained an understanding of the natural course and progression of severe asthma and the responses and adverse reactions to medications through long-term regular follow-ups. Moreover, we aimed to estimate the burden and treatment status of severe asthma and to develop better strategies for management of severe asthma in Korea. For this purpose, allergy or respiratory centers of the university hospitals and the members of the KAAACI working group (allergists or pulmonologists) have participated in this study (Supplementary Table 1). With the same study protocol and approval of the Institutional Review Board of each participating center, 31 centers in Korea have enrolled subjects with severe asthma (Fig. 2). We enrolled adult patients ( $\geq 18$ years old) with severe asthma who were treated

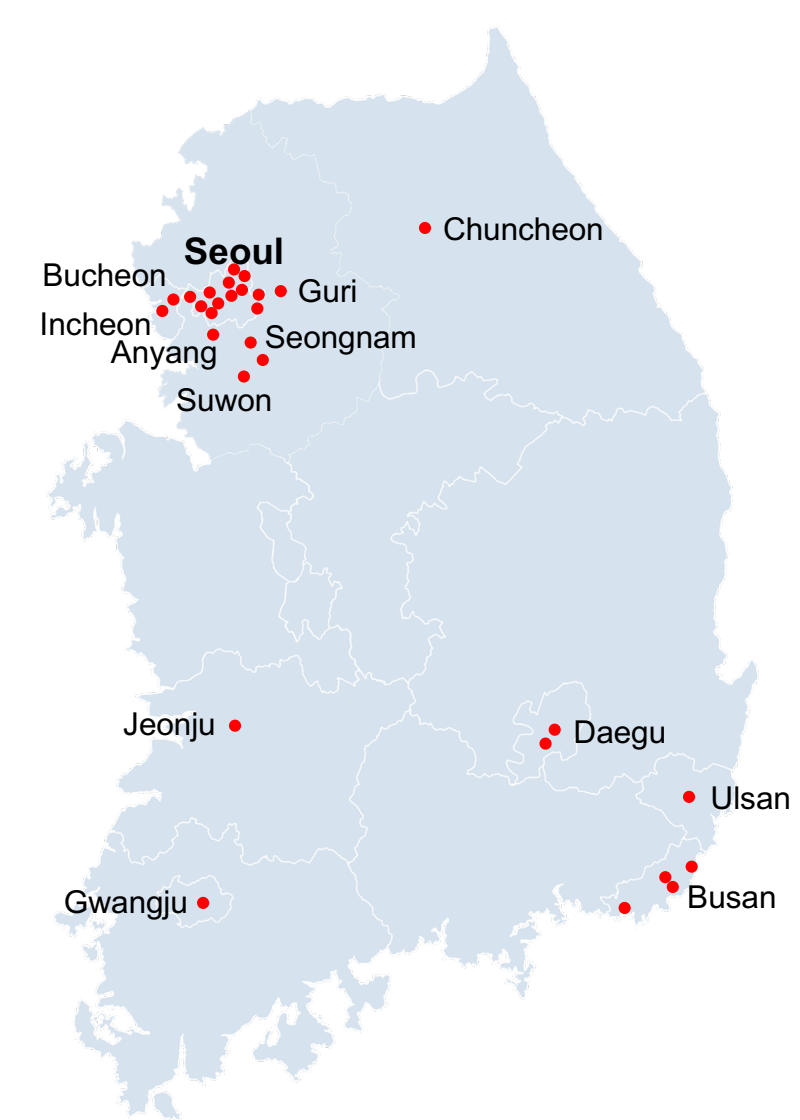

Figure 2. Locations of participating Korean Severe Asthma Registry (KoSAR) institutions.

for more than 1 year. Severe asthma was defined as uncontrolled despite the use of GINA step 4 or 5 treatment according to the international guidelines of the ERS and the ATS [7]. Asthma is defined as uncontrolled (1) when GINA step 4 or 5 treatment is unsuccessful or (2) when symptoms are relatively controlled with GINA step 4 or 5 treatment but frequent or serious exacerbations occur. At the time of enrollment, frequent exacerbation is defined as OCS bursts $\geq 3$ times per year, and serious exacerbation is defined as $\geq$ 1 hospitalization or visit to the emergency department per year. Uncontrolled asthma also includes any near-fatal exacerbation and loss of asthma control upon reduction of ICS or OCS dose. A web-based electronic case report form and electronic data capture system were used to collect and extract anonymized data from the enrolled subjects. The Data Management Committee evaluated the administered data quality at each center by programmed queries on the central web-based database of the KoSAR. Table 5 summarizes 
Table 5. KoSAR findings

\begin{tabular}{|c|c|}
\hline Category & Information \\
\hline Demographics & $\begin{array}{l}\text { Age, sex, height, weight, body mass index } \\
\text { Smoking status and past smoking } \\
\text { Previous and current occupations } \\
\text { Living area } \\
\text { Owning a pet }\end{array}$ \\
\hline Diagnosis & $\begin{array}{l}\text { Physician (specialist) diagnosis of asthma } \\
\text { Onset and duration of asthma } \\
\text { Treatment period of asthma } \\
\text { Family history of allergic diseases (asthma, allergic rhinitis, and atopic dermatitis) } \\
\text { Combined COPD }\end{array}$ \\
\hline Exacerbations & $\begin{array}{l}\text { Frequency of exacerbations and OCS bursts } \\
\text { Use of healthcare facilities: visits to outpatient department and emergency department, hospitalization, } \\
\text { and use of ICU }\end{array}$ \\
\hline $\begin{array}{l}\text { Asthma control and } \\
\text { quality of life }\end{array}$ & $\begin{array}{l}\text { Level of symptom control } \\
\text { Asthma Control Test }{ }^{\circledR} \\
\text { Quality of Life Questionnaire for Adult Korean Asthmatics }\end{array}$ \\
\hline Environmental factors & $\begin{array}{l}\text { Work-exacerbated asthma } \\
\text { Aspirin hypersensitivity } \\
\text { Aggravation during menstruation }\end{array}$ \\
\hline Comorbidities & $\begin{array}{l}\text { Current or previous history of diagnosis and duration } \\
\text { Current treatment } \\
\text { Allergic rhinitis: severity, comorbid sinusitis and nasal polyp, treatment } \\
\text { Atopic dermatitis, allergic conjunctivitis, GERD, sleep apnea, depression, anxiety disorder, diabetes mel- } \\
\text { litus, hypertension, heart failure, arrhythmia, cardiovascular disease, osteoporosis, and bronchiectasis } \\
\text { Previous history of pulmonary tuberculosis, pneumonia, pertussis, and measles }\end{array}$ \\
\hline Asthma medications & $\begin{array}{l}\text { Controllers including inhalers and biologics } \\
\text { OCS and immunosuppressant } \\
\text { Adherence to medications } \\
\text { Use of SABA }\end{array}$ \\
\hline Lung function tests & $\begin{array}{l}\text { Spirometry } \\
\text { Bronchodilator response } \\
\text { Lung volume } \\
\text { Bronchial provocation test }\end{array}$ \\
\hline Laboratory tests & $\begin{array}{l}\text { Skin prick test to aeroallergens } \\
\text { Peripheral blood eosinophils } \\
\text { Total IgE } \\
\text { Induced sputum analysis } \\
\text { Exhaled nitric oxide }\end{array}$ \\
\hline
\end{tabular}

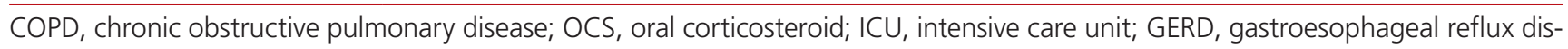
ease; SABA, short-acting beta2 agonist; IgE, immunoglobulin $\mathrm{E}$.

the data collected by the KoSAR. Longitudinal data also are collected by regular follow-up of the enrolled subjects.

\section{Observations from the KoSAR}

The demographic and clinical characteristics of severe asth- ma vary according to study subjects and their ethnic groups $[15,61]$. Compared with severe asthma patients enrolled in the registries from the European countries and the United States, the Korean patients with severe asthma were older (mean age of $62.3 \pm 14.0$ years) with older onset time 
(mean age of onset $40.8 \pm 17.4$ years) [4]. There were more females (54.9\%), similar to European countries in which the percentage of females ranged from $48.1 \%$ to $70.0 \%$. Body mass index was relatively lower in Korean patients with severe asthma than in Western countries. In terms of maintenance medications, Korean patients used more oral medications like leukotriene receptor antagonists and theophylline. The prescription of biologics was extremely low in Korea.

The KoSAR neither excluded nor restricted patients who smoke currently or who ceased smoking before enrollment, leading to inclusion of a substantial number of current smokers (12.3\%) and ex-smokers (33.7\%). In addition, the principal investigator of each institution determined if subjects could be diagnosed with ACO at the time of enrollment. About one-fourth of severe asthma patients in the KoSAR were classified as having ACO [27]. ACO patients required more frequent OCS bursts and emergency department visits for asthma exacerbations than those with asthma only. These findings suggest that a novel approach to severe asthma is needed considering COPD, as clinical trials of new therapeutic agents including biologics in severe asthma usually exclude subjects with diagnosis of COPD. Retrospective analysis of the effects and safety of therapeutic drugs using data from severe asthma registries would be of help in developing better strategies to manage severe asthma with features of COPD.

\section{KoSAR Biologics registry}

With a better understanding of the mechanisms of asthma, new therapeutic agents targeting the key molecules and cytokines in type 2 airway inflammation and immune responses in asthma have been developed. Biologics, mostly monoclonal antibodies inhibiting cytokines and receptors, have proven clinical benefits, especially in certain phenotypes of severe asthma. These benefits include reduction of exacerbations and improvement of asthma control, quality of life, and lung function $[62,63]$. Omalizumab, a monoclonal antibody to $\lg \mathrm{E}$, is the first biologic approved for treatment of uncontrolled allergic asthma [64]. Recently, monoclonal antibodies binding to IL-5 (mepolizumab and reslizumab), IL5R (benralizumab), and IL-4Ra (dupilumab) were developed and approved sequentially for Koreans with severe asthma. These biologics are expected to improve asthma control and quality of life of asthma sufferers.

While omalizumab was approved and introduced in clinical practice in 2007, in Korea, the prescription of omali- zumab has been low even in eligible patients with severe asthma [4]. In a 2015 survey of perceptions and practices concerning severe asthma, Korean asthma specialists responded that only $3.3 \%$ of the patients with severe asthma were prescribed biologics [11]. The use of biologics in severe asthma is much lower in Korea than in other countries [61]. The critical hurdle for the use of biologics is the high cost since most are not reimbursed by the Korean NHIS. In 2020, omalizumab was approved for reimbursement in cases of severe allergic asthma with frequent exacerbations and decreased lung function despite the use of high dose ICS, long-acting beta2-agonists, and LAMA. Reimbursement should be made for appropriate severe asthma patients upon assessment by an asthma specialist.

While clinical trials of biologics showed efficacy and safety in severe asthma, there are many questions that need to be answered. Australian investigators examined the effectiveness of omalizumab and mepolizumab and factors predictive of good response to these biologics using data from the Australian Xolair Registry [65] and the Australian Mepolizumab Registry [66]. The UK Severe Asthma Registry explored the effectiveness of mepolizumab in severe eosinophilic asthma by retrospective review of enrolled patients [67]. The Spanish Registry evaluated the efficacy and tolerability of omalizumab in patients with allergic asthma [48] and non-atopic asthma [68]. Severe asthma registries have the potential to evaluate the effectiveness, responses, and safety of biologics in everyday settings. Furthermore, the prescription patterns, causes of discontinuation, and switching of biologics could be assessed by analyzing data from the registries. To answer the various questions regarding biologics use, we organized the KoSAR Biologics registry (KoSAR-BIO). Recruitment of a large number of patients using biologics and collection of qualified data will provide the opportunity and power to conduct analyses.

\section{CONCLUSIONS}

Severe asthma needs to be acknowledged as a 'severe' disease considering the detrimental impacts on quality of life, socioeconomic cost, and life of the affected patient. Furthermore, the seriousness of severe asthma should be understood by patients, healthcare professionals, national governments, policymakers, pharmaceutical companies, and the public. As a recently suggested patient charter ar- 
gued [69], a specialized health policy and a dedicated campaign are needed to improve patient care in severe asthma. In line with the severe asthma registries in other countries, we organized the KOSAR to understand the characteristics, heterogeneity, and phenotypes of severe asthma in Korea. In the era of biologics for treatment of severe asthma, we hope to find ways to use biologics wisely and to improve treatment outcomes of severe asthmatic patients based on knowledge obtained from the KoSAR-BIO.

\section{Conflict of interest}

No potential conflict of interest relevant to this article was reported.

\section{Acknowledgments}

This work was supported by a grant of the Korea Health Technology R\&D Project through the Korea Health Industry Development Institute (KHIDI), funded by the Ministry of Health \& Welfare, Republic of Korea (grant number: HC19C0318). The authors thank the investigators, clinical research coordinators, and participants for their time and efforts in the KOSAR.

\section{REFERENCES}

1. Lee E, Kim A, Ye YM, Choi SE, Park HS. Increasing prevalence and mortality of asthma with age in Korea, 2002-2015: a nationwide, population-based study. Allergy Asthma Immunol Res 2020;12:467-484.

2. Kim SH, Kim TW, Kwon JW, et al. Economic costs for adult asthmatics according to severity and control status in Korean tertiary hospitals. J Asthma 2012;49:303-309.

3. Agache I, Cojanu C, Laculiceanu A, Rogozea L. Critical points on the use of biologicals in allergic diseases and asthma. Allergy Asthma Immunol Res 2020;12:24-41.

4. Kim MH, Kim SH, Park SY, et al. Characteristics of adult severe refractory asthma in Korea analyzed from the Severe Asthma Registry. Allergy Asthma Immunol Res 2019;11:43-54.

5. Bousquet J, Mantzouranis E, Cruz AA, et al. Uniform definition of asthma severity, control, and exacerbations: document presented for the World Health Organization Consultation on Severe Asthma. J Allergy Clin Immunol 2010;126:926-938.

6. Bel EH, Sousa A, Fleming $L$, et al. Diagnosis and definition of severe refractory asthma: an international consensus statement from the Innovative Medicine Initiative (IMI). Thorax
2011;66:910-917.

7. Chung KF, Wenzel SE, Brozek JL, et al. International ERS/ATS guidelines on definition, evaluation and treatment of severe asthma. Eur Respir J 2014;43:343-373.

8. Ryan D, Heatley $H$, Heaney LG, et al. Potential severe asthma hidden in UK primary care. J Allergy Clin Immunol Pract 2021;9:1612-1623.

9. Kim BK, Park SY, Ban GY, et al. Evaluation and management of difficult-to-treat and severe asthma: an expert opinion from the Korean Academy of Asthma, Allergy and Clinical Immunology, the Working Group on Severe Asthma. Allergy Asthma Immunol Res 2020;12:910-933.

10. Hekking PW, Wener RR, Amelink M, Zwinderman AH, Bouvy $\mathrm{ML}, \mathrm{Bel} \mathrm{EH}$. The prevalence of severe refractory asthma. J Allergy Clin Immunol 2015;135:896-902.

11. Kim SH, Moon JY, Lee JH, et al. Perceptions of severe asthma and asthma-COPD overlap syndrome among specialists: a questionnaire survey. Allergy Asthma Immunol Res 2018;10:225-235.

12. Lee YJ, Kwon SH, Hong SH, et al. Health care utilization and direct costs in mild, moderate, and severe adult asthma: a descriptive study using the 2014 South Korean Health Insurance Database. Clin Ther 2017;39:527-536.

13. Choi JY, Yoon HK, Lee JH, et al. Current status of asthma care in South Korea: nationwide the Health Insurance Review and Assessment Service database. J Thorac Dis 2017;9:32083214.

14. Jo EJ, Kim MY, Kim SH, et al. Implementation of asthma management guidelines and possible barriers in Korea. J Korean Med Sci 2020;35:e72.

15. van Bragt JJMH, Adcock IM, Bel EHD, et al. Characteristics and treatment regimens across ERS SHARP severe asthma registries. Eur Respir J 2020;55:1901163.

16. Lefebvre P, Duh MS, Lafeuille MH, et al. Acute and chronic systemic corticosteroid-related complications in patients with severe asthma. J Allergy Clin Immunol 2015;136:1488-1495.

17. Voorham J, Xu X, Price DB, et al. Healthcare resource utilization and costs associated with incremental systemic corticosteroid exposure in asthma. Allergy 2019;74:273-283.

18. Lee H, Ryu J, Nam E, et al. Increased mortality in patients with corticosteroid-dependent asthma: a nationwide population-based study. Eur Respir J 2019;54:1900804.

19. Song WJ, Won HK, Lee SY, et al. Patients' experiences of asthma exacerbation and management: a qualitative study of severe asthma. ERJ Open Res 2021;7:00528-2020.

20. Moore WC, Fitzpatrick AM, Li X, et al. Clinical heterogeneity 
in the severe asthma research program. Ann Am Thorac Soc 2013;10(Suppl):S118-S124.

21. Wenzel SE. Asthma: defining of the persistent adult phenotypes. Lancet 2006;368:804-813.

22. Agache I. Severe asthma phenotypes and endotypes. Semin Immunol 2019;46:101301.

23. Agache I, Akdis CA, Akdis M, et al. EAACl biologicals guidelines-recommendations for severe asthma. Allergy 2021;76:14-44.

24. McDonald VM, Hiles SA, Godbout K, et al. Treatable traits can be identified in a severe asthma registry and predict future exacerbations. Respirology 2019;24:37-47.

25. Agusti A, Bel E, Thomas M, et al. Treatable traits: toward precision medicine of chronic airway diseases. Eur Respir J 2016;47:410-419.

26. Kim MA, Park HW, Kim BK, et al. Specialist perception of severe asthma in Korea: a questionnaire survey. Allergy Asthma Immunol Res 2021;13:507-514.

27. Lee H, Kim SH, Kim BK, et al. Characteristics of specialist-diagnosed asthma-COPD overlap in severe asthma: observations from the Korean Severe Asthma Registry (KoSAR). Allergy 2021;76:223-232.

28. Kondo M, Tamaoki J. Therapeutic approaches of asthma and COPD overlap. Allergol Int 2018;67:187-90.

29. Holguin F, Cardet JC, Chung KF, et al. Management of severe asthma: a European Respiratory Society/American Thoracic Society guideline. Eur Respir J 2020;55:1900588.

30. Global Initiative for Asthma. Global Strategy for Asthma Management and Prevention [Internet]. Fontana (WI): GINA, 2022 [cited 2022 Jan 12]. Available from: http://www.ginasthma.org.

31. FitzGerald JM, Lemiere C, Lougheed MD, et al. Recognition and management of severe asthma: a Canadian Thoracic Society position statement. Can J Respir Crit Care Sleep Med 2017;1:199-221.

32. Lin J, Yang D, Huang M, et al. Chinese expert consensus on diagnosis and management of severe asthma. J Thorac Dis 2018;10:7020-7044.

33. Garcia G, Bergna M, Vasquez JC, et al. Severe asthma: adding new evidence: Latin American Thoracic Society. ERJ Open Res 2021;7:00318-2020.

34. Kerstjens HA, Maspero J, Chapman KR, et al. Once-daily, single-inhaler mometasone-indacaterol-glycopyrronium versus mometasone-indacaterol or twice-daily fluticasone-salmeterol in patients with inadequately controlled asthma (IRIDIUM): a randomised, double-blind, controlled phase 3 study. Lancet Respir Med 2020;8:1000-1012.
35. Lee LA, Bailes Z, Barnes N, et al. Efficacy and safety of once-daily single-inhaler triple therapy (FF/UMECNI) versus FF/ $\mathrm{VI}$ in patients with inadequately controlled asthma (CAPTAIN): a double-blind, randomised, phase 3A trial. Lancet Respir Med 2021;9:69-84.

36. Virchow JC, Kuna P, Paggiaro $P$, et al. Single inhaler extrafine triple therapy in uncontrolled asthma (TRIMARAN and TRIGGER): two double-blind, parallel-group, randomised, controlled phase 3 trials. Lancet 2019;394:1737-1749.

37. Sferrazza Papa GF, Milanese M, Facchini FM, Baiardini I. Role and challenges of severe asthma services: insights from the UK registry. Minerva Med 2017;108(3 Suppl 1):13-17.

38. Gibeon D, Heaney LG, Brightling CE, et al. Dedicated severe asthma services improve health-care use and quality of life. Chest 2015;148:870-876.

39. Expert Panel Working Group of the National Heart, Lung, and Blood Institute (NHLBI) administered and coordinated National Asthma Education and Prevention Program Coordinating Committee (NAEPPCC), Cloutier MM, Baptist AP, et al. 2020 Focused updates to the asthma management guidelines: a report from the National Asthma Education and Prevention Program Coordinating Committee Expert Panel Working Group. J Allergy Clin Immunol 2020;146:1217-1270.

40. McDonald VM, Vertigan AE, Gibson PG. How to set up a severe asthma service. Respirology 2011;16:900-911.

41. Burke H, Davis J, Evans S, Flower L, Tan A, Kurukulaaratchy RJ. A multidisciplinary team case management approach reduces the burden of frequent asthma admissions. ERJ Open Res 2016;2:00039-2016.

42. Gamble J, Stevenson M, Heaney LG. A study of a multi-level intervention to improve non-adherence in difficult to control asthma. Respir Med 2011;105:1308-1315.

43. FitzGerald JM, Alramezi Y. The challenges and opportunities of maximizing the benefits of severe asthma registries. J Allergy Clin Immunol Pract 2019;7:1469-1470.

44. Heaney LG, Brightling CE, Menzies-Gow A, Stevenson M, Niven RM; British Thoracic Society Difficult Asthma Network. Refractory asthma in the UK: cross-sectional findings from a UK multicentre registry. Thorax 2010;65:787-794.

45. Senna G, Guerriero M, Paggiaro PL, et al. SANI-Severe Asthma Network in Italy: a way forward to monitor severe asthma. Clin Mol Allergy 2017;15:9.

46. Pretolani M, Soussan D, Poirier I, et al. Clinical and biological characteristics of the French COBRA cohort of adult subjects with asthma. Eur Respir J 2017;50:1700019.

47. Schleich F, Brusselle G, Louis R, et al. Heterogeneity of pheno- 
types in severe asthmatics: the Belgian Severe Asthma Registry (BSAR). Respir Med 2014;108:1723-1732.

48. Vennera Mdel C, Perez De Llano L, Bardagi S, et al. Omalizumab therapy in severe asthma: experience from the Spanish registry: some new approaches. J Asthma 2012;49:416-422.

49. Sa-Sousa A, Fonseca JA, Pereira AM, et al. The Portuguese Severe Asthma Registry: development, features, and data sharing policies. Biomed Res Int 2018;2018:1495039.

50. Doberer $D$, Auer W, Loeffler-Ragg J, et al. The Austrian Severe Asthma Registry. Wien Klin Wochenschr 2015;127:821-822.

51. Korn S, Hubner M, Hamelmann E, Buhl R. Das Register "Schweres Asthma" [The German Severe Asthma Registry]. Pneumologie 2012;66:341-344.

52. Nenasheva N, Belevsky A. Characteristics of patients with severe asthma in the Russian Federation-the Russian Severe Asthma Registry. Am J Respir Crit Care Med 2019;199:A1337.

53. Ambrose CS, Chipps BE, Moore WC, et al. The CHRONICLE study of US adults with subspecialist-treated severe asthma: objectives, design, and initial results. Pragmat Obs Res 2020;11:77-90.

54. The Thoracic Society of Australia and New Zealand Leaders in Lung Health. Australasian Severe Asthma Registry [Internet]. Sydney (AU): TSANZ, 2022 [cited 2022 Jan 12]. Available from: https://www.thoracic.org.au/researchawards/australasian-severe-asthma-registry-asar.

55. Djukanovic R, Adcock IM, Anderson G, et al. The Severe Heterogeneous Asthma Research collaboration, Patient-centred (SHARP) ERS Clinical Research Collaboration: a new dawn in asthma research. Eur Respir J 2018;52:1801671.

56. Kirenga B, Chakaya J, Yimer G, et al. Phenotypic characteristics and asthma severity in an East African cohort of adults and adolescents with asthma: findings from the African severe asthma project. BMJ Open Respir Res 2020;7:e000484.

57. ISAR Study Group. International Severe Asthma Registry: mission statement. Chest 2020;157:805-814.

58. Wenzel SE, Busse WW; National Heart, Lung, and Blood Institute's Severe Asthma Research Program. Severe asthma: lessons from the Severe Asthma Research Program. J Allergy Clin Immunol 2007;119:14-21.
59. Jarjour NN, Erzurum SC, Bleecker ER, et al. Severe asthma: lessons learned from the National Heart, Lung, and Blood Institute Severe Asthma Research Program. Am J Respir Crit Care Med 2012;185:356-362.

60. Shaw DE, Sousa AR, Fowler SJ, et al. Clinical and inflammatory characteristics of the European U-BIOPRED adult severe asthma cohort. Eur Respir J 2015;46:1308-1321.

61. Wang E, Wechsler ME, Tran TN, et al. Characterization of severe asthma worldwide: data from the International Severe Asthma Registry. Chest 2020;157:790-804.

62. Agache I, Rocha C, Beltran J, et al. Efficacy and safety of treatment with biologicals (benralizumab, dupilumab and omalizumab) for severe allergic asthma: a systematic review for the EAACI Guidelines: recommendations on the use of biologicals in severe asthma. Allergy 2020;75:1043-1057.

63. Agache I, Beltran J, Akdis C, et al. A systematic review for the EAACl guidelines: recommendations on the use of biologicals in severe asthma. Allergy 2020;75:1023-1042.

64. Jung JW, Park HS, Park CS, et al. Effect of omalizumab as add-on therapy to Quality of Life Questionnaire for Korean Asthmatics (KAQLQ) in Korean patients with severe persistent allergic asthma. Korean J Intern Med 2021;36:1001-1013.

65. Gibson PG, Reddel H, McDonald VM, et al. Effectiveness and response predictors of omalizumab in a severe allergic asthma population with a high prevalence of comorbidities: the Australian Xolair Registry. Intern Med J 2016;46:1054-1062.

66. Harvey ES, Langton D, Katelaris C, et al. Mepolizumab effectiveness and identification of super-responders in severe asthma. Eur Respir J 2020;55:1902420.

67. Kavanagh JE, d'Ancona G, Elstad M, et al. Real-world effectiveness and the characteristics of a "super-responder" to mepolizumab in severe eosinophilic asthma. Chest 2020;158:491-500.

68. de Llano LP, Vennera Mdel C, Alvarez FJ, et al. Effects of omalizumab in non-atopic asthma: results from a Spanish multicenter registry. J Asthma 2013;50:296-301.

69. Menzies-Gow A, Canonica GW, Winders TA, Correia de Sousa J, Upham JW, Fink-Wagner AH. A charter to improve patient care in severe asthma. Adv Ther 2018;35:1485-1496. 
Kim SH, et al. Korean Severe Asthma Registry

\section{Supplementary Table 1. Korean Severe Asthma Registry (KoSAR) participating institutions and investigators}

\begin{tabular}{|c|c|c|}
\hline $\begin{array}{l}\text { Locations } \\
\text { (no. of institutions) }\end{array}$ & Institutions & Investigators \\
\hline \multirow[t]{14}{*}{ Seoul (14) } & Asan Medical Center & $\begin{array}{l}\text { You Sook Cho } \\
\text { Yeon-Mok Oh } \\
\text { Tae-Bum Kim } \\
\text { Hyouk-Soo Kwon } \\
\text { Woo-Jung Song } \\
\text { Ji-Hyang Lee }\end{array}$ \\
\hline & Chung-Ang University Hospital & Jae-Woo Jung \\
\hline & Ewha Womans University Mokdong Hospital & Young-Joo Cho \\
\hline & Ewha Womans University Seoul Hospital & $\begin{array}{l}\text { Min-Hye Kim } \\
\text { Ji-Su Shim }\end{array}$ \\
\hline & Eulji General Hospital & $\begin{array}{l}\text { Sang-Hoon Kim } \\
\text { So Young Park }\end{array}$ \\
\hline & Hanyang University Hospital & $\begin{array}{l}\text { Ho Joo Yoon } \\
\text { Sang-Heon Kim } \\
\text { Hyun Lee }\end{array}$ \\
\hline & Kangdong Sacred Heart Hospital & $\begin{array}{l}\text { Ga-Young Ban } \\
\text { Yong Suk Jo }\end{array}$ \\
\hline & Konkuk University Medical Center & $\begin{array}{l}\text { Kwang-Ha Yoo } \\
\text { So-Young Park }\end{array}$ \\
\hline & Korea University Anam Hospital & Byung-Keun Kim \\
\hline & Kyung Hee Medical Center & Kyoung-Hee Sohn \\
\hline & Samsung Medical Center & Byung-Jae Lee \\
\hline & Seoul National University Hospital & $\begin{array}{l}\text { Sang-Heon Cho } \\
\text { Heung-Woo Park } \\
\text { Hye-Ryun Kang } \\
\text { Suh-Young Lee }\end{array}$ \\
\hline & Seoul St. Mary's Hospital & $\begin{array}{l}\text { Chin Kook Lee } \\
\text { Hwa Young Lee }\end{array}$ \\
\hline & Severance Hospital & Jae-Hyun Lee \\
\hline Incheon (1) & Gachon University Gil Medical Center & Sung-Yoon Kang \\
\hline Guri (1) & Hanyang University Guri Hospital & Ji-Yong Moon \\
\hline Anyang (1) & Hallym University Sacred Heart Hospital & Joo-Hee Kim \\
\hline \multirow[t]{2}{*}{ Seongnam (2) } & CHA Bundang Medical Center & Mi-Ae Kim \\
\hline & Seoul National University Bundang Hospital & Yoon-Seok Chang \\
\hline Suwon (1) & Ajou University Hospital & $\begin{array}{l}\text { Hae-Sim Park } \\
\text { Youngsoo Lee }\end{array}$ \\
\hline Bucheon (1) & Soonchunhyang University Bucheon Hospital & $\begin{array}{l}\text { Choon-Sik Park } \\
\text { An-Soo Jang } \\
\text { Jong Sook Park }\end{array}$ \\
\hline Chuncheon (1) & Kangwon National University Hospital & Jae-Woo Kwon \\
\hline Jeonju (1) & Chonbuk National University Hospital & $\begin{array}{l}\text { Yong Chul Lee } \\
\text { So Ri Kim } \\
\text { Seoung Ju Park }\end{array}$ \\
\hline Gwangju (1) & Chonnam National University Hospital & $\begin{array}{l}\text { Young-\|l Koh } \\
\text { Da Woon Sim } \\
\text { Ji Eun Yu }\end{array}$ \\
\hline
\end{tabular}




\section{Supplementary Table 1. Continued}

\begin{tabular}{lll}
\hline $\begin{array}{l}\text { Locations } \\
\text { (no. of institutions) }\end{array}$ & Institutions & Investigators \\
\hline Daegu (2) & Kyungpook National University Hospital & Su-Jeong Kim \\
& Yeungnam University Hospital & Hyun Jung Jin \\
\hline Busan (4) & Dong-A University Hospital & Young-Hee Nam \\
& Inje University Haeundae Hospital & Chan Sun Park \\
& Kosin University Gospel Hospital & Hyo-Jung Kim \\
\hline Ulsan (1) & Pusan National University Hospital & Gil-Soon Choi \\
\hline & Ulsan University Hospital & Hye-Kyung Park \\
\hline
\end{tabular}

